\title{
Archibald V. Hill's contribution to science and society
}

\author{
Gerta Vrbová
}

Department of Cell and Developmental Biology, Faculty of Life Sciences, University College London, UK

\begin{abstract}
A brief account of A.V. Hill's contribution to our understanding of muscle contraction is given. This includes an overview of discoveries that led to solving the problem how chemical events provide the energy for mechanical work. Hill helped to train and educate a generation of scientists to use concise mathematical treatment of biological phenomena. He also taught his students moral values important when pursuing research. Finally Hill's deep belief in the international nature of scientific work and his human qualities led him to join Lord Rutherford to become founder member of the Academic Assistance Council, an organization that rescued around 1500 academics from Nazi occupied Europe during the Second World War. With all these activities taken together Hill can be considered a person who made an exceptionally important contribution to the cultural and scientific life of the 20th and 21st century.

Key Words: muscle contraction; energy for mechanical work; Academic Assistance Council
\end{abstract}

European Journal Translational Myology - Basic Applied Myology 2013; 23 (3): 73-76

On a Tuesday morning in March 2010 I was walking along the corridor to the Medical Sciences building at University College London (UCL), and a young girl, probably a student asked me to point out the way to the A.V. Hill Lecture Theatre. I stopped and before giving her the instructions how to find it, I asked her: 'Do you know who A.V. Hill was?' As expected her answer was: 'I have no idea, but I am in a hurry, we have a lecture on muscle physiology there, and I am late.'

I felt sad and disappointed by her lack of interest. However her ignorance and probably that of other students who attend lectures in the A.V. Hill lecture theatre prompted me to write a brief account of the significance of A.V. Hill for science and society.

In 1923 A.V. Hill succeeded Ernest Starling and was appointed to the post of Jodrell Professor of Physiology at UCL, a Department that already had an outstanding reputation and tradition. At the time of his appointment at UCL, Hill was a well-established scientists who had won the Nobel Prize in physiology in 1923 (as had Otto Meyerhoff).

He played a pivotal role in helping to bring mathematical rigor into physiology, for example by introducing the 'Hill equation' to explain the effects of the aggregation of hemoglobin molecules on its dissociation curves [5]. This equation is simple and widely deployed in bioscience and later proved useful in Hill's work on muscle.
Hill's arrival heralded new interesting developments at UCL. The first was the emphasis on progress made in the understanding of muscular contraction, and the second was Hill's dedication to establishing national and international cooperation between scientists. This included a commitment of actively helping scientists in need.

In 1933 Hill was a founder member and vice chairman of the Academic Assistance Council (AAC). This organization was dedicated to assist academics who for reasons including persecution and conflict were unable to continue their work in their country of origin. In the 30 s it included Jewish and other academics forced to flee the emerging Nazi regimes in Europe. By actively participating in the work of this organization Hill continued the liberal tradition of UCL set out in 1826 when the College was founded becoming the first secular institution of higher education in the UK. UCL then as now pledged that it would accept students of any race or religious or political belief.

In this brief article three main features of A.V. Hill's contribution to science and society will be discussed:

1. His scientific work.

2. His influence and inspiration to scientific colleagues internationally.

3. His contribution to assisting refugee academics. 


\section{A.V. Hill's contribution to science and society}

European Journal Translational Myology - Basic Applied Myology 2013; 23 (3): 73-76

\section{A.V. Hill Scientific Work}

When A.V. Hill arrived to UCL in 1923 the question as to how muscle uses energy from chemical reactions in order to do mechanical work was still obscure. At the beginning of the 20th century it was universally accepted that the primary biochemical reaction associated with providing energy for muscle contraction was lactic acid, released from a hypothetical large molecule called 'lactacidogen'. The hydrogen ions liberated were supposed to neutralize negative charges on the contractile protein filaments allowing them to fold and shorten. However there were several findings that were inconsistent with this idea, including measurements of heat production during muscle contraction made by Hill. It was therefore not surprising that this hypothesis was overthrown in what Hill called 'a revolution in muscle research', and can be considered the first of several such revolutions [7]. Hill dates the outbreak of this revolution to the end of 1926 when Philip and Grace Eggleton, research fellows in the Physiology and Biochemistry Department at UCL submitted a paper to the Biochemical Journal reporting that the amount of an unidentified organic phosphate compound present in muscle decreased during contraction with a corresponding increase in inorganic phosphate [3]. Although this weakened 'the lactic acid hypothesis', supporters of the lactic acid theory did not give up immediately. It was not until 1930 when Lundsgaard observed that a muscle that is poisoned with iodoacetatic acid and therefore cannot use oxygen to break down glycogen to form lactic acid is nevertheless able to perform several contractions [9]. Thus the energy required for this mechanical work has to be provided by reactions that did not require the production of lactic acid and the breakdown of organic phosphate molecules might be the source of this energy.

The position of organic phosphate in providing energy for mechanical work started the second revolution in muscle research. This was supported by evidence that suggested that the only pathway for the utilization of the phosphate from phosphorylcreatine was to rephosphorylate adenosine-diphosphate (ADP) to adenosine triphosphate (ATP), and it was soon accepted that the primary reaction providing energy for muscle contraction was the conversion of ATP to ADP plus inorganic phosphate. Conclusive proof for this idea was difficult to obtain because the rephosphorylation of ATP from ADP was extremely rapid and therefore no decrease in ATP could be detected during muscle contraction. However, in 1962 Cain, Infante and Davies demonstrated that a muscle poisoned with fluorodinitrobenzene could perform several contractions with the utilization of ATP but not of phosphorylcreatine [2].
An important discovery based on measurements of heat production during contraction by Hill and colleagues showed an increase in heat production and therefore of the amount of chemical change when the muscle was allowed to shorten [7]. This finding highlighted the importance of the relationship between the metabolic and mechanical conditions during contraction.

Measurement of heat production during muscle contraction, the method favored in Hills department also revealed some other fundamental processes of muscle physiology. Hill's mathematical treatment of muscle dynamics based on a biophysical model of muscle mechanics was the starting point of AF Huxley's model of muscle contraction [8], which remains the valid paradigm of the behavior of all motor protein and cell mobility systems.

The observation that oxygen is not needed during contraction but is necessary during recovery inspired the term 'oxygen debt' a useful concept in exercise physiology even today [7]. These were original and revolutionary discoveries that brought our understanding as to how chemical energy is converted to mechanical work, to a new level.

Hill considered measurement of physiological events using physical and electrical methods to be an important counterpart to other methods used in biology, partly because of the speed at which they can be recorded. His appreciation of the use of these techniques to examine biological processes inspired him to help to establish the first Department of Biophysics at UCL. After being awarded by the Royal Society the Foulerton Professorship in 1926 A.V. Hill became the first head of the Department of Biophysics and had been succeeded in 1952 by his pupil Bernard Katz, one of the scientists that were helped to leave Nazi Germany in 1935.

\section{A.V. Hill influence and inspiration to scientific colleagues internationally}

A.V. Hill had several PhD students. He is remembered by them with great affection, not only because of his scientific influence but also because of the way he treated them as human beings and colleagues. This is perhaps best described by his Chinese student TP Feng, who came to UCL in 1930 and stayed for 3 years. After returning to China Feng became the director of the Shanghai Institute of Physiology. In his memoirs TP Feng writes: 'The way Hill dealt with the first paper I wrote, entitled "The Heat-Tension Ratio in Prolonged Tetanic Contractions "is worth mentioning. The problem had been suggested by him and was carried out under his direction with much assistance from Mr. Parkinson, A.V. Hills' much appreciated and gifted technician. I naturally put Hill's name as a coauthor. He promptly took his name off the paper saying: "If this is the only paper you write while you are here it will not make much difference whether my name is on it or not, and it will not mean much to you". 


\section{A.V. Hill's contribution to science and society}

European Journal Translational Myology - Basic Applied Myology 2013; 23 (3): 73-76

Another remark in a similar vein at the end of my stay in London should also be retold. "You have done good work here and you have done most of the work independently. But people will still think that you are under my direction. You must go back and continue to do good work all by yourself, then you will be recognized as a fully independent worker." I don't know whether A.V. Hill talked to other students like this, but his words left a deep impression on me' [4]. Another of his students who wrote about him with much affection was his successor as head of the Department of Biophysics, Bernard Katz. After Katz fled Germany in 1935 he was accepted as a $\mathrm{PhD}$ student by A.V. Hill at UCL London, where he stayed until 1939. He referred to A.V. Hill as his greatest scientific influence and described this period as 'the most inspiring period of my life'.

Hill's influence on his pupils and colleagues was probably inspired by his strong sense of responsibility that scientists have in society and particularly the international nature of science. In an article in Science written during the Second World War he writes: 'It is nevertheless a fact that the nature of our occupation makes scientific men particular international in their outlook. In its judgment on facts science claims to be independent of political opinion, of nationality, of material profit. It believes that nature will give a single answer to any questions properly framed and that only one picture can ultimately be put together from the very complex jigsaw puzzle which the world presents. Individual and national bias, fashion, material advantage, a temporary emergency, may determine which part of the puzzle at any moment is subject to the greatest activity. For its final judgment however, for its estimates of scientific validity, there is a single court of appeal in nature itself, and nobody disputes its jurisdiction. Those who talk, for example of Aryan and non-Aryan physics or of proletarian and capitalist genetics, as though they were different simply make themselves ridiculous. For such reasons the community of scientific people throughout the world is convinced of international collaboration.' And later: 'In no other form of human activity, therefore, has so complete an internationalism spread throughout the national structure of society: in no other profession or craft is there so general an understanding or appreciation of fellow workers in other parts of the world. This implies no special merit or broadmindedness on the part of scientific men; it is their very good fortune, a good fortune which involves obligations as well as privileges. For example when the Nazis in 1933 began their persecution of Jews and liberals in Germany it was the scientific community in many other countries which came most quickly to the rescue of their colleagues; not out of any special generosity but because firstly they had personal knowledge of those who were being persecuted, and secondly they realized that such persecution struck at the basis of the position of science and scientific workers in society' and later : 'It may be then that through this by-product of international cooperation science may do as great a service to society (just as learning did in the Middle ages) as by any direct results in improving knowledge and controlling natural forces: not- as I would emphasize again- from any special virtue which we scientists have, but because in science world society can see a model of international cooperation carried on not merely for idealistic reasons but because it is the obvious and necessary basis of any system that is to work' [6].

These views and ideas motivated Hill to become a founder member of the Academic Assistance Council (AAC) an organization that offered help to Jewish and other liberal scientists persecuted in Nazi Germany and other fascist countries

\section{A.V. Hill and the Council for Assisting Refugee Academics}

In 1933 whilst studying in Vienna, William Beveridge the director of the London School of Economics learned that academics deemed 'undesirable' by the Nazi government either because they were Jews or of a different political opinion than the Nazis were dismissed from their position and unable to work. Dismayed by this, Beveridge returned to England keen to help these scholars [1]. He established the Academic Assistance Council (AAC) which later became Council for Assisting Refugee Academics (CARA) and finally The Society for Protection of Science and Learning (SPSL). This organization assisted academics forced to flee Nazi Germany, and later other countries ruled by Nazi Germany. He persuaded the prominent physicist Ernest Rutherford to become the first President and Hill Vice President of AAC.

In May 1933 Beveridge distributed a letter signed by many distinguished academics amongst them 5 Nobel laureates to publicize the new organization. The letter was published in major British newspapers. In June, Rutherford identified the charity's aims as twofold: 1 . to create a fund for academic assistance of displaced scholars, and 2. to act as a center of information, i.e. putting academics in touch with organizations that can best help them [11]. By the outbreak of the war the S.P.S.L. had aided at least 1500 scholars. A.V. Hill's commitment to the organization that enabled scientists to continue scientific work was expressed in his letter to Beveridge on New Year's Day 1934: 'It is not that these people will perish as human beings, but that as scholars and scientists they will have to take up something else in order to live.' With hindsight and our present knowledge of the Holocaust this statement seems to have greatly underestimated the dangers and perils faced by these scientists, who would have perished had they not got out of the countries ruled by Nazi Germany. Thus by helping their colleagues, 


\section{A.V. Hill's contribution to science and society}

European Journal Translational Myology - Basic Applied Myology 2013; 23 (3): 73-76

scientists more than any other intellectual group helped to defy the program to exterminate European Jews. This is in marked contrast to other professional organizations such as the medical or legal who for fear of competition did not offer help to their colleagues. Above all, as emphasized by Canadian historian David Zimmerman the role of the S.P.S.L. in the history of academic freedom has not been adequately recognized, and Zimmerman seeks to redress this. He writes that the S.P.S.L. became a quasi-government agent and helped to rescue a generation of European scholars [13]. Historian Gary Werskey emphasized the speed and efficiency with which the A.A.C. was established. He wrote, 'within a matter of weeks after the first expulsions of Jewish scholars from Germany, researchers like Hill and Lord Rutherford were able to set up an Academic Assistance Council'. The exceptional number of scientists rescued by this group who achieved ground breaking discoveries during their career is remarkable [12]. Scientific achievements are difficult to measure, but the number of Nobel prizes gives some indication. Before 1933 German scientists had won 33 prizes in science since 1900, the highest number of any nation, Britain won 18 and the USA 6 . After Hitler's rise to power 7 Nobel Prize winners left Germany and 20 of the refugees subsequently obtained the Nobel Prize [10].

It is likely that by rescuing a generation of scholars from Nazi ruled Europe A.V. Hill and other members of the S.P.S.L. contributed more to scientific development in the West then any single individual could achieve. Therefore AV.Hills views that international cooperation of scientists plays an important role for scientific achievement have been confirmed. His contribution to bring about this cooperation while at UCL gives the college a special place in helping to initiate outstanding scientific developments in science and is consistent with UCL's liberal and secular values.

\section{Conclusions}

Although A.V. Hill's contribution to the understanding of the problem of how chemical processes provide the energy to perform mechanical work in skeletal muscle was outstanding his equally important achievement was the realization that collaboration between scientists at national and international level can advance our understanding of the world around us more than the work of any single individual. Hill viewed the scientific community as a 'family' who's members strive to enhance our understanding of the world. By providing active help to individuals within this family Hill and others who assisted his efforts contributed more to advancing science then any single individual.

\section{Acknowledgements}

I am grateful to D. Miller who helped to add new information about AV Hill's work, and improved my spelling.

\section{Corresponding Author}

G. Vrbová, Dept. of Cell and Dev. Biology, Faculty of Life Sciences, University College London, WC1E 6BT, UK. As from: 25, Ellington Rd. London N10 3DD, UK. E-mail: g.vrbova@ucl.ac.uk

\section{References}

[1] Beveridge WH. Power and Influence. London Hodder and Stoughton 1953; 234-235.

[2] Cain DF, Infante EE, Davies RE. Adenosine triphosphate and phosphorylcreatine as energy suppliers for single contractions of working muscle. Nature 1962;196:214-217.

[3] Eggleton P., Eggleton GP. The inorganic phosphate and labile form of organic phosphate in the gastrocnemius of the frog. Biochem $\mathrm{J}$ 1927;21:190-195.

[4] Feng Tei Pei. Muscle Nerve and Synapse, ed. by Xiong-Li Yang, Director of the Institute of Physiology Shanghai, August 1994.

[5] Hill AV. The possible effects of the aggregation of the molecules of hemoglobin on its dissociation curves .J. Physiol. 1910;40: (suppl. iv-vii).

[6] Hill AV. Science National and International and the basis of cooperation. Science 1941;93: 579584.

[7] Hill AV. Trails and trials in Physiology. London. Arnold 1965.

[8] Huxley AF. Muscular contraction. J. Physiol. 1974; 243: 1-43.

[9] Lundsgaard E. Untersuchungen über Muskelkontraktionen ohne Milchsäurebindung. Biochem. Zeit. 1930;217: 162-77.

[10] Pyke D. Contributions by German emigrés to British medical science. QJM. 2000;93:487495.

[11] Rutherford E. The British Academic Assistance Council. Science New Series 1933;77: 620-621.

[12] Werskey G. The visible College. London Free Association books 1988; 244.

[13] Zimmmerman D. The Society for The Protection of Science and Learning and the Politicization of British Science in the 1930th. Minerva 2006; 44: 25-45. 